\title{
Errata
}

ISSN 1678-3921

Journal homepage: www.embrapa.br/pab

For manuscript submission and journal contents, access: www.scielo.br/pab

\section{ERRATA: Assessment of somaclonal variation in indirect morphogenesis- derived plants of Arracacia xanthorrhiza}

In the paper "Assessment of somaclonal variation in indirect morphogenesis-derived plants of Arracacia xanthorrhiza", DOI: 10.1590/S1678-3921.pab2019.v54.00301, published in Pesquisa Agropecuária Brasileira, v.54, e00301, 2019, on page 2, left column, second paragraph, line 6 , where it reads:

"Slerotinia sclerotiorum",

it should read:

"Sclerotinia sclerotiorum". 